\title{
Direct north-south synchronization of abrupt climate change record in ice cores using Beryllium 10
}

\author{
G. M. Raisbeck ${ }^{1}$, F. Yiou ${ }^{1}$, J. Jouzel ${ }^{2}$, and T. F. Stocker ${ }^{3}$ \\ ${ }^{1}$ Centre de Spectrométrie Nucléaire et de Spectrométrie de Masse, IN2P3-CNRS-Université de Paris-Sud, Bât. 108, 91405 \\ Orsay, France \\ ${ }^{2}$ IPSL/LSCE, UMR CEA-CNRS-UVSQ, CE Saclay, 91191 Gif-sur-Yvette, France \\ ${ }^{3}$ Climate and Environmental Physics, Physics Institute, University of Bern, Sidlerstrasse 5, 3012 Bern, Switzerland
}

Received: 24 April 2007 - Published in Clim. Past Discuss.: 11 May 2007

Revised: 7 August 2007 - Accepted: 5 September 2007 - Published: 7 September 2007

\begin{abstract}
A new, decadally resolved record of the ${ }^{10} \mathrm{Be}$ peak at $41 \mathrm{kyr}$ from the EPICA Dome $\mathrm{C}$ ice core (Antarctica) is used to match it with the same peak in the GRIP ice core (Greenland). This permits a direct synchronisation of the climatic variations around this time period, independent of uncertainties related to the ice age-gas age difference in ice cores. Dansgaard-Oeschger event 10 is in the period of best synchronisation and is found to be coeval with an Antarctic temperature maximum. Simulations using a thermal bipolar seesaw model agree reasonably well with the observed relative climate chronology in these two cores. They also reproduce three Antarctic warming events observed between A1 and $\mathrm{A} 2$.
\end{abstract}

\section{Introduction}

Precise correlation of Northern and Southern Hemisphere ice core records is of critical importance for the understanding of the dynamics of abrupt climatic changes during the last glacial period that have been inferred from the isotopic records in the GRIP (Johnsen et al., 1992; Dansgaard et al., 1993) and GISP2 (Grootes et al., 1993) ice cores from Central Greenland during the late glacial period. Twenty-five of these so-called Dansgaard/Oeschger events (DO events), characterized by a rapid warming and a more gradual return to glacial conditions, were identified between 110 and $14 \mathrm{kyr}$ BP (North GRIP members, 2004) (1 kyr BP is 1000 years before present). That the largest of these abrupt changes seemed to have attenuated counterparts in Antarctica was noted from a visual comparison with the isotopic record from the East Antarctic Vostok core (Jouzel et al., 1994). Based

Correspondence to: G. M. Raisbeck

(raisbeck@csnsm.in2p3.fr) on the comparison of the $\delta^{18} \mathrm{O}$ records in air bubbles, Bender et al. (1994) proposed a first synchronization of Greenland and Antarctic large glacial events for the period $>46 \mathrm{kyr} \mathrm{BP}$. Uncertainties of about $\pm 3 \mathrm{kyr}$ in relative dating, due in large part to the uncertainty in the ice age - gas age difference (Delta age), made it impossible to determine whether events in Greenland and Antarctic ice cores were in phase or out of phase (Bender et al., 1994), or in a lead/lag relationship (Steig and Alley, 2002; Schmittner et al., 2003).

Yiou et al. (1997) proposed a direct synchronization based on the use of the ${ }^{10} \mathrm{Be}$ peak measured in 5 ice cores around $40 \mathrm{kyr}$ BP. The advantages of this method are that ${ }^{10} \mathrm{Be}$ is recorded in the ice rather than in the gases, and that its production is independent of climate. In Greenland ice this ${ }^{10} \mathrm{Be}$ peak straddles DO 10 (Yiou et al., 1997) which occurred between the two major DO events 8 and DO 12. Similar to the Greenland isotopic record, Yiou et al. (1997) noted that in the Vostok core there are 3 secondary isotopic maxima between the Antarctic counterparts of DO 8 and DO 12, later named A1 and A2 (Blunier et al., 1998), with the ${ }^{10}$ Be peak occurring slightly after the second of these events. This would imply that the event corresponding to DO 10 occurred in Antarctica slightly earlier than in Greenland. However, the precision of the timing was limited by the fact that the ${ }^{10} \mathrm{Be}$ and $\delta \mathrm{D}$ measurements were made on two different Vostok cores (see note added in proof of Yiou et al., 1997).

Since then the synchronization of Greenland and Antarctic glacial records has focused on the use of gas indicators. Rapid methane concentration changes proved very powerful for this purpose. Taking advantage of the relatively high accumulation at the Byrd site in West Antarctica, which results in low delta age uncertainty, Blunier et al. (1998) showed that, comparing their starting points, the long lasting DO 8 and DO 12 warming events lag their A1 and A2 Antarctic

Published by Copernicus Publications on behalf of the European Geosciences Union. 
counterparts by 2 to $3 \mathrm{kyr}$. This conclusion was extended to the seven major millennial-scale Antarctic warmings, A1 to A7, clearly identified back to $90 \mathrm{kyr}$ (Blunier and Brook, 2001) and further to A8/DO 23 and A9/DO 24 (Caillon et al., 2003; Landais et al., 2006). A further, gas-based synchronization was derived from a very detailed comparison of the Vostok and GISP2 $\delta^{18} \mathrm{O}$ of air records (Bender et al., 1999). It showed that all 15 long and short interstadial events identified in the GISP2 ice core between 38 and 72 ka have counterparts in the Vostok record. On average, all these events are in phase between Greenland and Antarctica (within $\pm 1.3 \mathrm{kyr}$ ). Importantly, the contradiction between the methane and $\delta^{18} \mathrm{O}$ of air approaches appears to be largely a matter of definition simply due to the different shapes of Greenland and Antarctic events. As noted in Blunier and Brook (2001), a comparison of peak temperatures as done in Bender et al. (1999), rather than the leading edges, would also lead to the conclusion that Byrd and Greenland (GRIP and GISP2) events are in phase. Most recently, methane synchronization of a core from Dronning Maud Land (EDML) with GRIP and NGRIP confirmed that all the DO events had Antarctic counterparts, and improved the relative GreenlandAntarctic chronologies to 400-800 years in the last glacial period (EPICA Community Members, 2006). We adopt the suggestion made in that paper to refer to these Antarctic counterparts as AIM (Antarctic Isotope Maximum).

There are two limitations to the use of gases for synchronization: (i) it is applicable only at times where there is a rapid change in the atmospheric value, (ii) the signal is retained at the "close-off" depth (typically about $80 \mathrm{~m}$ ) where the bubbles in the ice are isolated from the overlying atmosphere. This signal is thus both smoothed and shifted compared to records in the ice itself. The resulting age offset is particularly important in low accumulation rate regions, such as the Antarctic plateau, where it can be as large as $5 \mathrm{kyr}$ or more during glacial periods.

Here we show that the cosmogenic isotope ${ }^{10} \mathrm{Be}$ is a parameter that permits the synchronisation of paleoclimatic records, because large changes in its production, caused by modulation of the galactic cosmic ray intensity by the geomagnetic field and the electric and magnetic fields associated with the out-flowing solar wind, are globally synchronous and independent of climate. The successful application of such a procedure requires that one can extract the ${ }^{10} \mathrm{Be}$ production rate variations from those caused by changes in deposition patterns (which themselves can be dependent on climate), and that the variations are characteristic enough to identify in the records being examined.

The strongest and most reliably identified excursion of high ${ }^{10} \mathrm{Be}$ concentrations is found in several ice cores from Antarctica and Greenland (Yiou et al., 1997; Raisbeck et al., 1987; Beer et al., 1992), as well as in marine sediment cores (McHargue et al., 1995; Castagnoli et al., 1995; Robinson et al., 1995) 40 000 years ago, and now generally accepted to be associated with the Laschamp geomagnetic excursion.
We report here new high resolution measurements of this ${ }^{10}$ Be peak on samples from the EPICA Dome C ice core and combine these with a ${ }^{10} \mathrm{Be}$ record from the GRIP core in order to determine the relative phasing of temperature changes recorded in Greenland and Antarctica.

Although these data are being formally presented here for the first time, the position of this ${ }^{10} \mathrm{Be}$ peak in the EPICA core has been available for some time (Raisbeck et al., 2002), and has been used to help construct or support chronologies discussed in several papers of this special issue (Parrenin et al., 2007; Ruth et al., 2007; Blunier et al., 2007; Loulergue et al., 2007) and elsewhere (EPICA Community Members, 2006; Jouzel et al., 2007).

\section{Experimental procedure}

The ice available for this study was in the form of a continuous series of $55 \mathrm{~cm}$ strips, each weighing $\sim 300 \mathrm{~g}$. In order to maximize the time resolution, each bag was divided into 5 samples of $11 \mathrm{~cm}$ in length, each representing $\sim 9$ years. The amount of ice per sample $(\sim 50 \mathrm{~g})$ is almost an order of magnitude smaller than what we have used for previous studies (Raisbeck et al., 1987; Yiou et al., 1997). We therefore have modified somewhat our previous procedure. The samples were melted in $250 \mathrm{ml}$ centrifuge cones, in the presence of $0.25 \mathrm{mg}$ of ${ }^{9} \mathrm{Be}$ carrier. The $\mathrm{Be}(\mathrm{OH})_{2}$ was then precipitated directly with $\mathrm{NH}_{4} \mathrm{OH}$. The precipitate was then washed with water $(\mathrm{pH}=7)$, dissolved in a few drops of nitric acid, and transferred to a quartz crucible. The crucible was taken to dryness on a hotplate, then heated to $900^{\circ}$ over an electric furnace in order to transform the precipitate to $\mathrm{BeO}$. The $\mathrm{BeO}$ was mixed with $\mathrm{Nb}$ powder (325 mesh) in the ratio $3: 1$ and pressed into a $1 \mathrm{~mm}$ diameter, $1 \mathrm{~mm}$ deep hole in a Mo cathode. This cathode was heated in argon to $1200^{\circ}$ for $1 \mathrm{~min}$, then $1800^{\circ}$ for an additional minute, in a resistively heated carbon furnace. This procedure was found to give better and more stable ${ }^{9} \mathrm{Be}$ currents in the ion source, as well as reduce ${ }^{10} \mathrm{~B}$ interference. The ${ }^{10} \mathrm{Be} /{ }^{9} \mathrm{Be}$ ratios were measured at the Gif-sur-Yvette Tandetron based AMS facility, relative to NIST standard SRM 4325, using the certified ratio of $2.68 \times 10^{-11}$. For almost all samples, at least $200 \mathrm{Be}$ events were recorded, leading to a 1 sigma statistical uncertainty of $<7 \%$. Combined with a conservatively estimated $5 \%$ machine uncertainty, this leads to an overall uncertainty of $\sim 8.5 \%$.

\section{Results}

The ${ }^{10} \mathrm{Be}$ peak is centred at $740 \mathrm{~m}$ (Fig. 1), and shows structure on centennial and even decadal time scales (Raisbeck et al., 2002). This suggests that the peak is due to a combination of low geomagnetic field intensity and periods of variable solar activity. The effects of the latter are enhanced because 


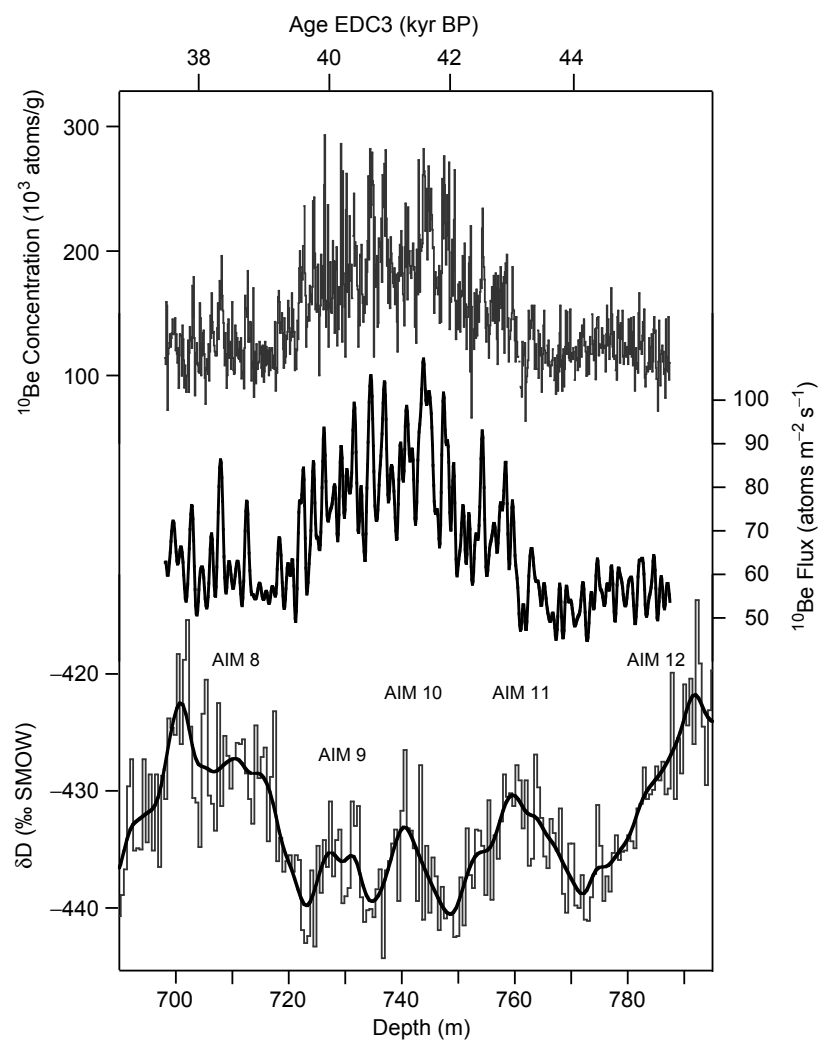

Fig. 1. ${ }^{10} \mathrm{Be}$ concentrations, ${ }^{10} \mathrm{Be}$ flux and deuterium ratio and its running average as a function of depth and age (EDC3) in the EPICA Dome $\mathrm{C}$ ice core. The ${ }^{10} \mathrm{Be}$ flux has been calculated using accumulation rates used for EDC3 (Parrenin et al., 2007), and smoothed by summing the 5 first components provided by the singular spectral analysis of the record (Paillard et al., 1996). Antarctic equivalents of DO events 8 to 12 are labeled AIM 8 to 12, where AIM stands for Antarctic Isotope Maximum.

they occur during the interval of low geomagnetic field intensity (With a "normal" geomagnetic field, a large fraction of cosmic rays with energies $<1 \mathrm{GeV}$ are already excluded from the atmosphere, and are thus insensitive to solar modulation). ${ }^{10} \mathrm{Be}$ reaches the Antarctic plateau primarily by dry deposition, and hence concentrations are inversely correlated with the snow accumulation rate. A more appropriate parameter to use when studying production variations is the ${ }^{10} \mathrm{Be}$ flux which is the product of the measured concentrations and the estimated accumulation rates (Raisbeck et al., 1992).

The $\delta \mathrm{D}$ profile in the interval between 700 and $800 \mathrm{~m}$ has 3 features (i.e., AIM 9 to 11) that, based on their position and pattern, were identified as subdued analogues of DO events 9 to 11 observed in Greenland. The most prominent part of the ${ }^{10} \mathrm{Be}$ peak straddles the middle one of these events (AIM 10) (Raisbeck et al., 2002), exactly as seen in the GRIP core (Yiou et al., 1997). This implies that DO 10 and its Antarctic counterpart are synchronous in the two ice cores.

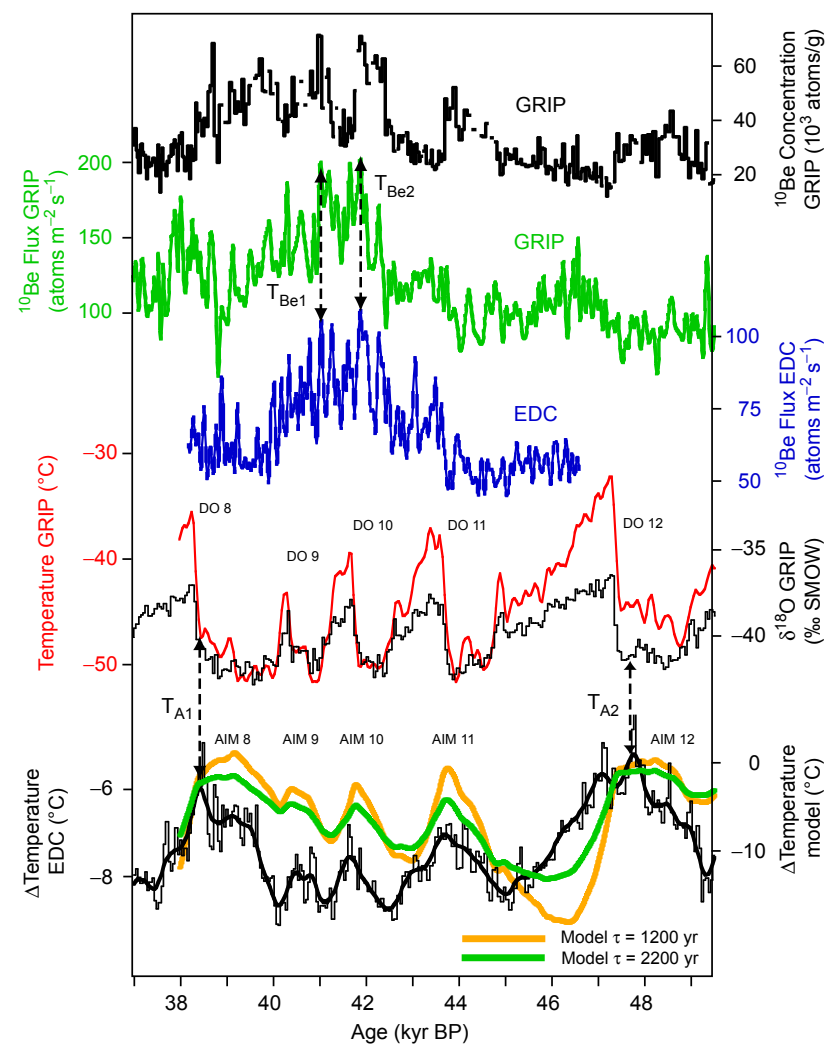

Fig. 2. Synchronization of the GRIP and EPICA Dome C records on the SS09sea time-scale (North GRIP Members, 2004), using the four tie points of Table $1 .{ }^{10} \mathrm{Be}$ concentrations are mainly from Yiou et al. (1997) with additional measurements from Wagner et al. (2001) and Muscheler et al. (2004). Corrections for ${ }^{10} \mathrm{Be}$ retained on filters for GRIP samples processed with 0.45 micron filters have been made as described in Yiou et al. (1997). GRIP fluxes, calculated using the accumulation estimates of Johnsen et al. (2001) after applying a correction for the change in the isotopic composition of the ocean (Waelbroeck et al., 2002), are smoothed by singular spectral analysis as in Fig. 1. The two following curves show $\delta^{18} \mathrm{O}$ at GRIP and estimated temperature change as given by $\mathrm{Hu}-$ ber et al. (2006) at NorthGRIP, these two records being placed on a common timescale (North GRIP Members, 2004) and scaled in such a way that the $\delta^{18} \mathrm{O}$ record corresponds to the temperature change derived using the present-day temperature isotope relationship as observed along traverses (Johnsen et al., 1989). The bottom curve represent the Dome C temperature change (Stenni et al., 2004) without source correction and its running average. This can be compared with the predicted southern temperature response using the thermal bipolar seesaw model (Stocker and Johnsen, 2003), with a $\tau$ of 1200 and 2200 years.

Figure 2 shows two features $(\mathrm{Be} 1$ and $\mathrm{Be} 2)$ which we believe can be reliably identified in the ${ }^{10} \mathrm{Be}$ flux curves of Dome $\mathrm{C}$ and GRIP. At this depth, the time resolution of the GRIP ${ }^{10} \mathrm{Be}$ measurements is from $\sim 30-50$ years. In order to have comparable resolution, we have therefore resampled both data at 10 year intervals, and smoothed them 


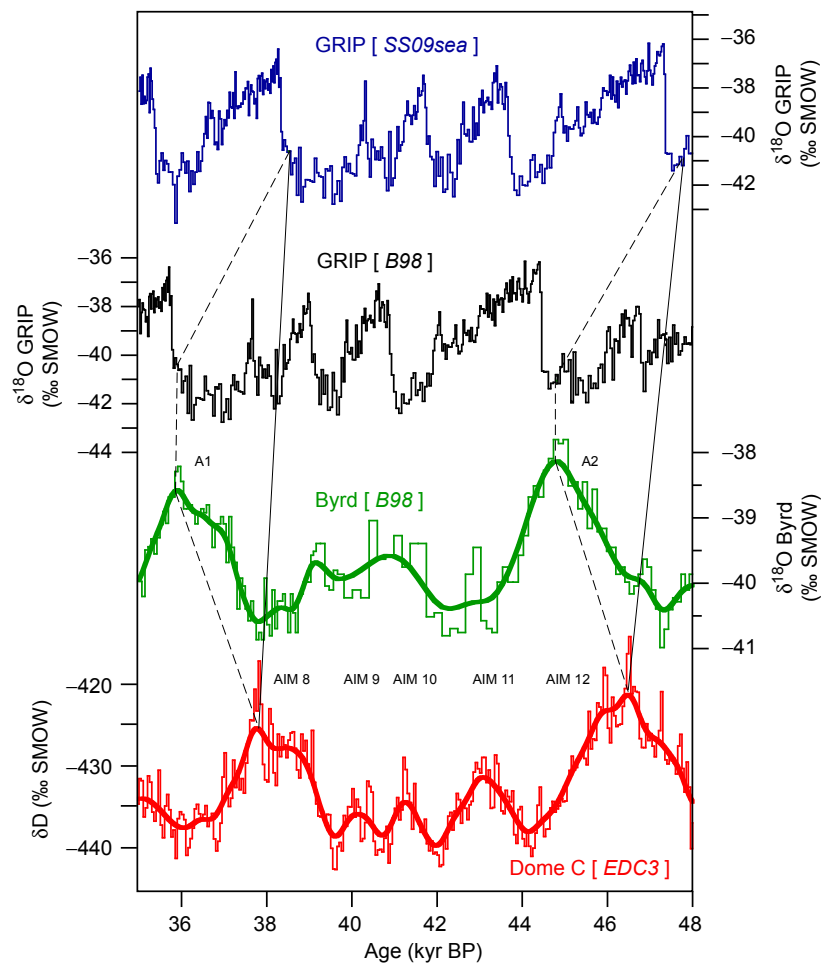

Fig. 3. Isotope profiles of GRIP, Byrd and EDC cores, showing how the correlation of A1 and A2 by Blunier et al. (1998) (vertical dashed lines) between GRIP and Byrd (on the timescale adopted by Blunier et al.) has been transferred onto those of the SS09sea time scale of GRIP and the EDC3 time scale of Dome C, giving rise to the tie points (solid lines) shown in Table 1 and Fig. 2.

by summing the first 5 components of a singular spectral analysis (Paillard et al., 1996). Using these smoothed curves for alignment, DO 10 and its counterpart, AIM 10 are synchronous in the two records, within our ability to resolve, which we presently estimate as $\sim 200$ years.

Due to limitations of the GRIP ${ }^{10} \mathrm{Be}$ record (time resolution, missing samples, corrections for filtered samples), we do not feel confident in making ${ }^{10} \mathrm{Be}$ correlations outside the main peak region. In order to show correlation over a more extended period, we have thus used the A1 and A2 methane events as synchronized between GRIP and the Byrd core by Blunier et al. (1998). These have been transferred from Byrd to EDC as shown in Fig. 3 and Table 1. We then correlated the two curves using the Analyseries program (Paillard et al., 1996). We emphasize that the accuracy of the external correlations does not effect the ${ }^{10} \mathrm{Be}$ synchronization in the region of AIM 10. As one goes away from this region however, the correlation will become increasingly dependent on these external tie points. One observation in favour of at least the older of these external tie points is the near coincidence of a minor ${ }^{10} \mathrm{Be}$ peak at $\sim 44 \mathrm{ky}$, which two reviewers of this paper thought should correlate. Interestingly enough, the use of these external tie points also brings a modeled response of
Table 1. Tie points used for correlating GRIP and EDC ice cores in Fig. 2.

\begin{tabular}{lcccc}
\hline Tie point & $\begin{array}{c}\text { Depth } \\
\text { EDC } \\
(\mathrm{m})\end{array}$ & $\begin{array}{c}\text { Depth } \\
\text { GRIP } \\
(\mathrm{m})\end{array}$ & $\begin{array}{c}\text { Age } \\
\text { EDC3 } \\
(\mathrm{kyr})\end{array}$ & $\begin{array}{c}\text { Age GRIP } \\
\text { SS09sea } \\
(\mathrm{kyr})\end{array}$ \\
\hline $\mathrm{T}_{\mathrm{A} 1}$ & 701.7 & 2202.0 & 37.81 & 38.45 \\
$\mathrm{~T}_{\mathrm{Be} 1}{ }^{*}$ & 734.5 & 2231.6 & 40.67 & 41.04 \\
$\mathrm{~T}_{\mathrm{Be} 2}{ }^{*}$ & 743.8 & 2245.2 & 41.54 & 41.89 \\
$\mathrm{~T}_{\mathrm{A} 2}$ & 793.1 & 2327.9 & 46.5 & 47.71 \\
\hline
\end{tabular}

* These values are slightly different, but within the uncertainties, of those used by Loulergue et al. (2007).

AIM 11 in good phase agreement with the observations (see below).

This synchronism for DO 10 and its Antarctic counterpart complements and reinforces results based on the methane records of Antarctic and Greenland ice cores (Blunier et al., 1998) which demonstrated that the start of the warming associated with events A1 and A2 lead the abrupt warming of DO 8 and 12, respectively, by 2-3 kyr. Because of the duration of $\mathrm{A} 1$ and $\mathrm{A} 2$, however, this is equivalent to the alternative statement that the maximum temperature during $\mathrm{A} 1$ and A2 coincided with that of DO 8 and DO 12, respectively. For the period in between, with the three intervening DO events 9 to 11 , a statement regarding the phase relationship between Greenland and Antarctica for other DO events was not possible owing to the noisier $\delta^{18} \mathrm{O}$ record of the Byrd ice core and the general uncertainty in synchronizing shorter events based on gas records.

\section{Implications for bipolar seasaw model}

The fact that between A1 and A2 three additional Antarctic temperature maxima can be identified in the EPICA Dome $\mathrm{C}$ ice core, and that the middle of these can be precisely synchronized with DO 10 in the Greenland ice cores via the ${ }^{10} \mathrm{Be}$ peak, lends strong support for the thermal bipolar seesaw operating throughout the sequence of DO events (Broecker, 1998; Stocker, 1998; Stocker and Johnsen, 2003). This model assumes that temperature anomalies associated with the abrupt climate changes in Greenland occur in antiphase with those in the South Atlantic (Stocker, 1998) due to the effect of the meridional overturning circulation in the Atlantic Ocean on the oceanic meridional heat flux (Crowley, 1992; Knutti et al., 2004). An important extension of the original concept (Crowley, 1992) is that the Southern Ocean acts as a heat reservoir for temperature anomalies and hence, only a damped and time-integrated signal of the abrupt changes in the north is transmitted to Antarctica. The thermal bipolar seesaw involves a typical heat exchange time scale $\tau$. The best correlation between the simulated southern signal based 
on the seesaw model and the reconstructed Antarctic temperature was obtained with $\tau \approx 1200$ years (Stocker and Johnsen, 2003).

We now test the thermal bipolar seesaw concept with the new synchronization based on ${ }^{10} \mathrm{Be}$. The new temperature reconstructions based on thermal fractionation measured on air enclosed in samples from the NorthGRIP ice core (Huber et al., 2006) is used as input to the seesaw model with $\tau=1200$ and 2200 years. The output is compared to the temperature record at Dome $\mathrm{C}$ inferred from the $\delta \mathrm{D}$ signal (Stenni et al., 2004). Because the bipolar seesaw model of Stocker and Johnsen (2003) concerns ocean temperatures, while the input and output are estimates of air temperatures, one cannot expect the predicted temperature variations to be quantitatively comparable to those inferred from the ice cores. Indeed, as seen in Fig. 2, the observed variations are $\sim 5$ times smaller than those predicted, emphasizing that the thermal bipolar seesaw model is a simple, conceptual model. Nevertheless, the model captures correctly the phasing, and to some extent also the relative amplitude, of the observed variations. As can be seen in Fig. 2, for both values of $\tau$ the southern temperature response of the seesaw model in the time period from 49 to $38 \mathrm{kyr}$ BP exhibits all warmings and coolings which are inferred from the $\delta \mathrm{D}$ record from EPICA Dome C. For AIM 9-11, the time difference between the predicted and observed temperature peaks is $<200$ years, which is about the limit of the estimated uncertainty in our synchronization. Not only the phasing of the simulated signal, but also the relative amplitudes are reasonably well produced.

\section{Perspectives}

While it would be desirable to apply the ${ }^{10} \mathrm{Be}$ technique to other time intervals of the climate records, we unfortunately have not yet identified other events during the last climate cycle which are as dramatic as the ${ }^{10} \mathrm{Be}$ peaks around $40 \mathrm{kyr} \mathrm{BP}$. However, if continuous high resolution ${ }^{10} \mathrm{Be}$ profiles were available, it still should be possible to make such a correlation using the centennial scale variations. For example, at Vostok, it was possible to correlate the variations produced by solar modulation with similar variations observed in tree ring ${ }^{14} \mathrm{C}$ (Raisbeck et al., 1998). In principle, therefore, it should be feasible to correlate such variations in Antarctic and Greenland ice. As mentioned above, the degree of correlation in Fig. 2 is limited by the GRIP ${ }^{10} \mathrm{Be}$ record. Thus, an improved Greenland ${ }^{10} \mathrm{Be}$ record should allow a better correlation. We have now measured such a profile in the North GRIP core at a resolution comparable to that measured at Dome C. This should potentially permit a correlation on a time scale of better than 20 years. As noted earlier, the largest and longest of the ${ }^{10} \mathrm{Be}$ production variations should also be identifiable in marine sediments, further permitting a direct correlation of the ice core and ocean climatic records.
Acknowledgements. Constructive comments from three reviewers are acknowledged. This work is a contribution to the "European Project for Ice Coring in Antarctica" (EPICA), a joint ESF (European Science Foundation)/EU scientific programme, funded by the European Commission (EPICA-MIS) and by national contributions from Belgium, Denmark, France, Germany, Italy, Netherlands, Norway, Sweden, Switzerland and the United Kingdom. The main logistic support was provided by IPEV and PNRA (at Dome C) and AWI (at Dronning Maud Land). Tandetron operation was supported by the IN2P3 and INSU divisions of the CNRS. This is EPICA publication no. 183.

Edited by: F. Parrenin

\section{References}

Beer, J., Johnsen, S. J., Bonani, G., Finkel, R. C., Langway, C. C., Oeschger, H., Stauffer, B., Suter M., and Wölfli, W.: ${ }^{10} \mathrm{Be}$ peaks as time markers in polar ice core records, in: The Last Deglaciation: Absolute and Radiocarbon Chronologies, edited by: Bard, E. and Broecker, W. S., Springer, New York, 141-143, 1992.

Bender, M., Sowers, T., Dickson, M.-L., Orchardo, J., Grootes, P., Mayewski, P. A., and Meese, D. A.: Climate correlations between Greenland and Antarctica during the past 100000 years, Nature, 372, 663-666, 1994.

Bender, M., Malaizé, B., Orchardo, J., Sowers, T., and Jouzel, J.: High precision correlations of Greenland and Antarctic ice core records over the last $100 \mathrm{kyr}$, in: Mechanisms of Global Climate Change at Millennial Time Scales, edited by: Clark, P. U., Webb, D. J., Keigwin, L. D., American Geophysical Union, Washington, vol. 112, pp. 149-164, 1999.

Blunier, T. and Brook, E. J.: Timing of millennial-scale climate change in Antarctica and Greenland during the last glacial period, Science, 291, 109-112, 2001.

Blunier, T., Chappellaz, J., Schwander, J., Dallenbach, A., Stauffer, B., Stocker, T. F., Raynaud, D., Jouzel, J., Clausen, H. B., Hammer, C. U., and Johnsen, S. J., Asynchrony of Antarctic and Greenland climate change during the last glacial period, Nature, 394(6695), 739-743, 1998.

Blunier, T., Spahni, R., Barnola, J. M., Loulergue, L., and Schwander, J.: Synchronization of ice core records via atmospheric gases, Clim. Past, 3, 325-330, 2007, http://www.clim-past.net/3/325/2007/.

Broecker, W. S.: Paleocean circulation during the last deglaciation: a bipolar seesaw?, Paleoceanography, 13, 119-121, 1998.

Caillon, N., Jouzel, J., Severinghaus, J. P., Chappellaz, J., and Blunier, T.: A novel method to study the phase relationship between Antarctic and Greenland climate, Geophys. Res. Lett., 30(17), 1899-2002, 2003.

Castagnoli, G. C., Albrecht, A., Beer, J., Bonino, G., Shen, C., Callegari, E., Taricco, C., Dittrich-Hannen, B., Kubik, P., Suter, M., and Zhu, G. M.: Evidence for enhanced Be-10 deposition in Mediterranean sediments 35-Kyr BP, Geophys. Res. Lett., 22(6), 707-710, 1995.

Crowley, T. J.: North Atlantic deep water cools the southern hemisphere, Paleoceanography, 7, 489-497, 1992.

Dansgaard, W., Johnsen, S. J., Clausen, H. B., Dahl-Jensen, D., Gundestrup, N. S., Hammer, C. U., Hvidberg, C. S., Steffensen, 
J. P., Sveinbjörnsdottir, A. E., Jouzel, J., and Bond, G.: Evidence for general instability of past climate from a 250-kyr ice-core record, Nature, 364, 218-220, 1993.

EPICA Community Members: Eight glacial cycles from an Antarctic ice core, Nature, 429, 623-628, 2004.

EPICA Community Members: Interhemispheric coupling of millenial scale variability during the last glacial, Nature, 444, 195198, 2006.

Grootes, P. M., Stuiver, M., White, J. W. C., Johnsen, S., and Jouzel, J.: Comparison of oxygen isotope records from the GISP2 and GRIP Greenland ice cores, Nature, 366, 552-554, 1993.

Huber, C., Leuenberger, M., Spahni, R., Flückiger, J., Schwander, J., Stocker, T. F., Johnsen, S., Landais, A., and Jouzel, J.: Isotope calibrated Greenland temperature record over Marine Isotope Stage 3 and its relation to CH4, Earth Planet. Sci. Lett., 243, 504-519, 2006.

Johnsen, S. J., Dansgaard, W., and White, J. W. C.: The origin of Arctic precipitation under present and glacial conditions, Tellus, 41B, 452-468, 1989.

Johnsen, S. J., Clausen, H. B., Dansgaard, W., Fuhrer, K., Gundestrup, N., Hammer, C. U., Iversen, P., Jouzel, J., Stauffer, B., and Steffensen, J. P.: Irregular glacial interstadials recorded in a new Greenland ice core, Nature, 359, 311-313, 1992.

Johnsen, S. J., DahlJensen, D., Gundestrup, N., Steffensen, J. P., Clausen, H. B., Miller, H., Masson-Delmotte, V., Sveinbjornsdottir, A. E., and White, J.: Oxygen isotope and palaeotemperature records from six Greenland ice-core stations: Camp Century, Dye-3, GRIP, GISP2, Renland and NorthGRIP, J. Quat. Sci., 16(4), 299-307, 2001.

Jouzel, J., Lorius, C., Johnsen, S., and Grootes, P.: Climate instabilities - Greenland and Antarctic records, Comptes Rendus de l'Académie des Sciences Série II, 319(1), 65-77, 1994.

Jouzel, J., Masson-Delmotte, V., Cattani, O., Dreyfus, G., Falourd, S.,Hoffmann, G., Minster, B., Nouet, J., Barnola, J. M., Chappellaz, J., Fischer, H., Gallet, J. C., Johnsen, S., Leuenberger, M., Loulergue, L., Luethi, D., Oerter, H., Parrenin, F., Raisbeck, G., Raynaud, D., Schilt, A., Schwander, J., Selmo, E., Souchez, R., Spahni, R., Stauffer, B., Steffensen, J. P., Stenni, B., Stocker, T. F., Tison, J. L., Werner, M., and Wolff, E. W.: Orbital and millenial Antarctic climate variability over the last 800000 years, Science, 317, 793-796, doi:10.1126/science.1141038, 2007.

Knutti, R., Flückiger, J., Stocker, T. F., and Timmermann, A.: Strong hemispheric coupling of glacial climate through freshwater discharge and ocean circulation, Nature, 430, 851-856, 2004.

Landais, A., Masson-Delmotte, V., Jouzel, J., Raynaud, D., Johnsen, S., Huber, C., Leuenberger, M., Schwander, J., and Minster, B.: The glacial inception as recorded in the NorthGRIP Greenland ice core: timing, structure and associated abrupt temperature changes, Clim. Dynam., 26(2-3), 273-284, 2006.

Loulergue, L., Parrenin, F., Blunier, T., Barnola, J.-M., Spahni, R., Scilt, A., Raisbeck, G., and Chappellaz, J.: New constraints on the gas age-ice age difference along the EPICA ice cores, 050 kyr, Clim. Past, 3, 527-540, 2007,

http://www.clim-past.net/3/527/2007/.

McHargue, L. R., Damon, P. E., and Donahue, D. J.: Enhanced cosmic-ray production of Be-10 coincident with the Mono Lake and Laschamp geomagnetic excursions, Geophys. Res. Lett., 22(5), 659-662, 1995.

Muscheler, R., Beer, J., Wagner, G., Laj, C., Kissel, C., Raisbeck,
G. M., Yiou, F., and Kubik, P. W.: Changes in the carbon cycle during the last deglaciation as indicated by the comparison of Be10 and C-14 records, Earth Planet. Sci. Lett., 219(3-4), 325-340, 2004.

North GRIP Members: High-resolution climate record of the northern hemisphere back into the last interglacial period, Nature, 431, 147-151, 2004.

Paillard, D., Labeyrie, L. D., and Yiou, P.: Macintosh program performs time-series analysis, EOS, Transactions of the American Geophysical Union, 77, 379, 1996.

Parrenin, F., Barnola, J.-M., Beer, J., Blunier, T., Castellano, E., Chappellaz, J., Dreyfus, G., Fischer, H., Fujita, S., Jouzel, J., Kawamura, K., Lemieux, B., Loulergue, L., Masson-Delmotte, V., Narcisi, B., Petit, J.-R., Raisbeck, G. M., Raynaud, D., Ruth, U., Schwander, J., Severi, M., Spahni, R., Steffensen, J. P., Svensson, A., Udisti, R., Waelbroeck, C., and Wolff, E. The EDC3 agescale for the EPICA Dome C ice core, Clim. Past, 3, 485-497, 2007, http://www.clim-past.net/3/485/2007/.

Raisbeck, G. M., Yiou, F., Bourlès, D., Lorius, C., Jouzel, J., and Barkov, N. I., Evidence for two intervals of enhanced Be-10 deposition in Antarctic ice during the last glacial period, Nature, 326(6110), 273-277, 1987.

Raisbeck, G. M., Yiou, F., Jouzel, J., Petit, J. R., Bard, E., and Barkov, N. I.: ${ }^{10}$ Be deposition at Vostok, Antarctica, during the last 50000 years and its relationship to possible cosmogenic production variations during this period, in: The Last Deglaciation: Absolute and Radiocarbon Chronologies, edited by: Bard, E. and Broecker, W. S., Springer, New York, 127-139, 1992.

Raisbeck, G. M., Yiou, F., Bard, E., Dollfus, D., Jouzel, J., and Petit, J. R.: Absolute dating of the last 7000 years of the Vostok ice core using ${ }^{10} \mathrm{Be}$, Mineralogical Magazine, 62A, 1228, 1998.

Raisbeck, G. M., Yiou, F., and Jouzel, J.: Cosmogenic ${ }^{10} \mathrm{Be}$ as a high resolution correlation tool for climate records, Geochim. Cosmochim. Acta, 66, A623, 2002.

Robinson, C., Raisbeck, G. M., Yiou, F., Lehman, B., and Laj, C.: The relationship between $\mathrm{Be}-10$ and geomagnetic field strength records in central North Atlantic sediments during the last $80 \mathrm{ka}$, Earth Planet. Sci. Lett., 136(3-4), 551-557, 1995.

Ruth, U., Barnola, J.-M., Beer, J., Bigler, M., Blunier, T., Castellano, E., Fischer, H., Fundel, F., Huybrechts, P., Kaufmann, P., Kipfstuhl, J., Lambrecht, A., Morganti, A., Oerter, H., Parrenin, F., Rybak, O., Severi, M., Udisti, R., Wilhelms, F., and Wolff, E.: EDML1: A chronology for the EDML ice core, Antarctica, over the last 150000 years, Clim. Past, 3, 474-484, 2007, http://www.clim-past.net/3/474/2007/.

Schmittner, A., Saenko, O. A., and Weaver, A. J.: Coupling of the hemispheres in observations and simulations of glacial climate change, Quat. Sci. Rev., 22, 659-671, 2003.

Steig, E. J. and Alley, R. B.: Phase relationships between Antarctic and Greenland climate records, Ann. Glaciol., 35, 451-456, 2002.

Stenni, B., Jouzel, J., Masson-Delmotte, V., Roethlisberger, R., Castellano, E., Cattani, O., Falourd, S., Johnsen, S. J., Longinelli, A., Sachs, J. P., Selmo, E., Souchez, R., Steffensen, J. P., and Udisti, R.: A late-glacial high-resolution site and source temperature record derived from the EPICA Dome C isotope records (East Antarctica), Earth Planet. Sci. Lett., 217(1-2), 183-195, 2004. 
Stocker, T. F.: The seesaw effect, Science, 282, 61-62, 1998.

Stocker, T. F. and Johnsen, S. J.: A minimum thermodynamic model for the bipolar seesaw, Paleoceanography, 18, 1087, doi:10.1029/2003PA000920, 2003.

Waelbroeck, C., Labeyrie, L., Michel, E., Duplessy, J. C., McManus, J. F., Lambeck, K., Balbon, E., and Labracherie, M.: Sea-level and deep water temperature changes derived from benthic foraminifera isotopic records, Quat. Sci. Rev., 21(1-3), 295$305,2002$.
Wagner, G., Beer, J., Masarik, J., Muscheler, R., Kubik, P. W., Mende, W., Laj, C., Raisbeck, G. M., and Yiou, F.: Presence of the solar de Vries cycle ( $\sim 205$ years) during the last ice age, Geophys. Res. Lett., 28(2), 303-306, 2001.

Yiou, F., Raisbeck, G. M., Baumgartner, S., Beer, J., Hammer, C., Johnsen, S., Jouzel, J., Kubik, P. W., Lestringuez, J., Stievenard, M., Suter, M., and Yiou, P., Beryllium 10 in the Greenland Ice Core Project ice core at Summit, Greenland, J. Geophys. Res., 102, 26783-26794, 1997. 